\title{
Evaluation of blood metabolites in dairy cows grazing under two pasture allowances and supplemented with corn silage under restricted grazing conditions
}

\author{
Álvaro Morales ${ }^{1}$, Daniela Grob¹, Fernando Wittwer², Ananda Müller², Óscar Balocchi ${ }^{3}$, \\ Rubén Pulido ${ }^{1}$ \\ ${ }^{1}$ Universidad Austral de Chile, Instituto de Ciencia Animal, Valdivia, Los Ríos, Chile. \\ ${ }^{2}$ Universidad Austral de Chile, Instituto de Ciencias Clinicas Veterinarias, Valdivia, Los Ríos, Chile. \\ ${ }^{3}$ Universidad Austral de Chile, Instituto de Producción Animal, Valdivia, Los Ríos, Chile.
}

\begin{abstract}
This study was conducted to evaluate the influence of management tools - daily pasture allowance and corn silage supplementation - during periods of forage shortage on the metabolism of dairy cows grazing low-mass pasture in temperate regions. Forty lactating Holstein cows were used during an experimental period of seventy days (April 15 to June 23, 2012). Blood metabolites and milk production were determined in fall-calving dairy cows grazing under two daily pasture allowances (PA) (moderate, $17 \mathrm{~kg}$ vs. high, $25 \mathrm{~kg}$ dry matter (DM)) and supplemented with corn silage (CS) (low, $4.5 \mathrm{~kg}$ vs. high, $9.0 \mathrm{~kg} \mathrm{DM}$ ). All cows received $3 \mathrm{~kg}$ DM of concentrate. Plasma concentrations of $\beta$-hydroxybutyrate (BHBA), nonesterified fatty acids (NEFA), and urea were determined using an automated spectrophotometer, and milk production was electronically measured at each milking time during the trial. The experimental design was completely randomized using a $2 \times 2$ factorial arrangement of treatments. The increase in daily PA decreased plasma concentrations of BHBA $(0.91 \pm 0.36$ vs. $\left.1.12 \pm 0.43 \mathrm{mmol} \mathrm{L}^{-1}\right)$, provided an increase in milk yield $\left(23.18 \pm 3.26 \mathrm{vs} .21 .99 \pm 3.37 \mathrm{~kg} \mathrm{~d}^{-1}\right)$, and did not modify the concentrations of NEFA and urea. The increased CS supplementation increased mildly the plasma concentrations of BHBA $\left(1.07 \pm 0.36\right.$ vs. $\left.0.96 \pm 0.44 \mathrm{mmol} \mathrm{L}{ }^{-1}\right)$ and NEFA $\left(92.77 \pm 54.14\right.$ vs. $\left.92.77 \pm 55.31 \mu \mathrm{mol} \mathrm{L}^{-1}\right)$, and decreased the concentrations of urea $\left(4.08 \pm 1.40\right.$ vs. $\left.4.64 \pm 1.30 \mathrm{mmol} \mathrm{L}^{-1}\right)$, but did not change milk production. The positive effect of increasing PA was associated with a high herbage intake, while the lack of response to increasing CS supplementation was attributed to a high substitution of pasture intake (0.9 kg DM pasture/kg DM CS). Low corn silage supplementation is recommended.
\end{abstract}

Key Words: dairy cow, grazing system, metabolism, restricted feeding, supplementation

\section{Introduction}

It is widely recognized that grazing pasture is the cheapest and most abundant food source for dairy farms in temperate regions (Dillon, 2006). However, the pastures have a marked seasonal variation in production and herbage quality, which affects dry matter (DM) content and nutrient intake (Poff et al., 2011). Particularly, the fall pasture presents a low DM content and herbage mass $\left(<170 \mathrm{~g} \mathrm{~kg}^{-1}\right.$; $\leq 1.800 \mathrm{~kg} \mathrm{DM} \mathrm{ha}^{-1}$, respectively), which limits feed intake (Ruiz-Albarrán et al., 2012). In addition, high crude protein content (200 to $300 \mathrm{~g} \mathrm{~kg}^{-1} \mathrm{DM}$ ) and low nonstructural carbohydrates (50 to $250 \mathrm{~g} \mathrm{~kg}^{-1} \mathrm{DM}$ ) are present and generate a lack of synchrony in the ruminal degradation of both fractions (Pulido et al., 2010). The foregoing, in

Received January 20, 2016 and accepted July 16, 2016.

Corresponding author: rpulido@uach.cl

http://dx.doi.org/10.1590/S1806-92902016001100007

Copyright (c) 2016 Sociedade Brasileira de Zootecnia. This is an Open Access article distributed under the terms of the Creative Commons Attribution License (http://creativecommons.org/licenses/by/4.0/), which permits unrestricted use, distribution, and reproduction in any medium, provided the original work is properly cited. addition to the increase of requirements on fall-calving dairy cows, ensures that pasture diets alone are generally insufficient to meet the requirements of dairy cattle (PérezPrieto et al., 2011), predisposing the presentation of metabolic-nutritional imbalances (Ingvartsen et al., 2003).

Metabolic profiles are used to evaluate these phenomena in the herd (Payne et al., 1970). The measurement of specific metabolites allows the evaluation of adequacy of the main metabolic pathways associated with energy, protein, and minerals and then provides useful information related to nutrition and animal health to optimize the productive and reproductive potential of cows (Kida, 2003; Macrae et al., 2006).

Metabolic disorders of nutritional origin are common in the first months of lactation, because cows are accompanied by a degree of negative energy balance, increasing the rate of mobilization of lipid reserves and increasing concentrations of NEFA and ketone bodies in blood and milk (Gross et al., 2011; Urdl et al., 2015). During periods of herbage shortage and swards with low herbage mass, to control the presentation of nutritional metabolism imbalances and mitigate the effects of an 
unbalanced diet based on pasture, the use of supplementary food is necessary to ensure a stable supply in quantity and quality of nutrients, in conjunction with proper grazing management (Bjerre-Harpøth et al., 2012; Barrientos et al., 2013; Morales et al., 2014; Ruiz-Albarrán et al., 2016).

The aim of this study was to determine the effect of pasture allowance (PA) and corn silage (CS) supplementation on energy and protein indicators of metabolism of fallcalving dairy cows in early lactation grazing low-mass pasture in southern Chile.

\section{Material and Methods}

This study was approved by the Committee for Animal Use in Research of Universidad Austral de Chile, in accordance with the ethical principles of animal experimentation.

The experiment was conducted in Valdivia, Chile $\left(39^{\circ} 47^{\prime} \mathrm{S}\right.$ latitude, and $73^{\circ} 14^{\prime} \mathrm{W}$ longitude) at a height of $12 \mathrm{~m}$ a.s.l. The soil type corresponded to a series Andisol Valdivia (Typic Hapludand) of flat topography. The experiment lasted 70 days and was conducted in the fall between April and June, 2012.

Forty multiparous Holstein Friesian dairy cows from the dairy herd of the university (milk yield $24.1 \pm 2.8 \mathrm{~kg} \mathrm{~d}^{-1}$; parity $3.5 \pm 1.6$; days in milk $62.7 \pm 14 \mathrm{~d}$; and body weight $538 \pm 46 \mathrm{~kg}$ ) were randomly assigned to four dietary treatments resulting from the combination of two PA above ground level: $17 \mathrm{~kg} \mathrm{DM} \mathrm{cow}^{-1} \mathrm{~d}^{-1}$ (moderate PA) and
$25 \mathrm{~kg} \mathrm{DM} \mathrm{cow}^{-1} \mathrm{~d}^{-1}$ (high PA) and two levels of corn silage supplementation: $4.5 \mathrm{~kg} \mathrm{DM} \mathrm{cow}^{-1} \mathrm{~d}^{-1}$ (low CS) and $9.0 \mathrm{~kg}$ DM $\operatorname{cow}^{-1} \mathrm{~d}^{-1}$ (high CS). All of the cows received $3 \mathrm{~kg}$ DM cow ${ }^{-1} \mathrm{~d}^{-1}$ of concentrate supplementation (Table 1). The base concentrate contained, on a DM basis, $493 \mathrm{~g} \mathrm{~kg}^{-1}$ corn, $300 \mathrm{~g} \mathrm{~kg}^{-1}$ sugar beet pulp, $115 \mathrm{~g} \mathrm{~kg}^{-1}$ soybean meal, $46 \mathrm{~g} \mathrm{~kg}^{-1}$ beet molasses, and $45 \mathrm{~g} \mathrm{~kg}^{-1}$ mineral mixture, and was offered equally into each milking.

Grazing took place on a 10.6 ha ryegrass dominant pasture (Lolium perenne) (Table 1), with each treatment herd grazing at the same paddock, but separated by an electric fence according to the corresponding PA. All animals were given access to new pasture after each milking under a rotational grazing system, with two rotations over the duration of this study.

To deliver the PA, pre-grazing compressed sward height was measured daily, using a rising plate meter (Filip's folding plate pasture meter, Jenquip, New Zealand), taking 100 measurements randomly walking the paddocks in a "W" pattern. Then the grazing area was calculated by converting the compressed sward height into $\mathrm{kg} \mathrm{DM} \mathrm{ha}^{-1}$ using a linear regression equation developed for the fall (Canseco et al., 2009). The same methodology was used to evaluate the post-grazing residual.

The CS was made on the farm (Table 1) and was offered in the pre-milking waiting yard using headlocks, thus avoiding competitiveness between animals, providing $60 \%$ of the diet after the morning milking and the remaining before the afternoon milking.

Table 1 - Chemical composition of the herbage (moderate and high pasture allowances, PA) and supplements offered throughout the experiment ${ }^{1}$

\begin{tabular}{|c|c|c|c|c|c|c|c|c|c|}
\hline & \multicolumn{4}{|c|}{ Pasture } & \multirow{3}{*}{ P-value } & \multicolumn{2}{|c|}{ Corn silage } & \multicolumn{2}{|c|}{ Concentrate $^{3}$} \\
\hline & \multicolumn{2}{|c|}{ Moderate PA } & \multicolumn{2}{|c|}{ High PA } & & \multirow{2}{*}{\multicolumn{2}{|c|}{$\overline{\mathrm{X}} \pm \mathrm{SD}$}} & \multirow{2}{*}{\multicolumn{2}{|c|}{$\overline{\mathrm{X}} \pm \mathrm{SD}$}} \\
\hline & \multicolumn{2}{|c|}{$\overline{\mathrm{X}} \pm \mathrm{SD}$} & \multicolumn{2}{|c|}{$\overline{\mathrm{X}} \pm \mathrm{SD}$} & & & & & \\
\hline Dry matter & 126 & 29 & 127 & 26 & 0.92 & 360 & 33 & 873 & 3 \\
\hline Ash & 97 & 12 & 95 & 9 & 0.64 & 45 & 4 & 44 & 2 \\
\hline Crude protein & 248 & 29 & 249 & 32 & 0.98 & 94 & 5 & 152 & 1 \\
\hline Neutral detergent fiber & 537 & 38 & 541 & 39 & 0.87 & 472 & 8 & 219 & 24 \\
\hline Acid detergent fiber & 213 & 7 & 211 & 13 & 0.64 & 262 & 5 & 108 & 0.1 \\
\hline Soluble carbohydrates & 74 & 14.2 & 75 & 14.5 & 0.91 & - & - & - & - \\
\hline $\mathrm{NFC}^{2}$ & 92 & 71 & 92 & 72 & 0.99 & 357 & 6 & 553 & 18 \\
\hline Soluble protein & 86 & 18 & 82 & 17 & 0.65 & - & - & - & - \\
\hline “D” value (\%) & 78.9 & 1.6 & 78.7 & 2.3 & 0.88 & 75.9 & - & 87.6 & - \\
\hline
\end{tabular}

$\mathrm{SD}$ - standard deviation; ME - metabolizable energy; NFC - non-fiber carbohydrates; "D" value - content of digestible organic matter in the dry matter; $\mathrm{N}-\mathrm{NH}_{3}$ - ammonia nitrogen.

- values not determined.

${ }^{1}$ Data are presented as $\mathrm{g} \mathrm{kg}^{-1}$ of dry matter unless otherwise indicated.

${ }^{2} \mathrm{NFC}=100-(\operatorname{ash}(\%)+\mathrm{CP}(\%)+\mathrm{EE}(\%)+\mathrm{NDF}(\%))$.

${ }^{3}$ Concentrate was prepared especially for this experiment by IANSAGRO S.A. 
A mineral mix $\left(\mathrm{Ca}, 140 \mathrm{~g} \mathrm{~kg}^{-1} ; \mathrm{P}, 100 \mathrm{~g} \mathrm{~kg}^{-1} ; \mathrm{Mg}\right.$, $60 \mathrm{~g} \mathrm{~kg}^{-1}$; Na, $40 \mathrm{~g} \mathrm{~kg}^{-1} ; \mathrm{S}, 2 \mathrm{~g} \mathrm{~kg}^{-1} ; \mathrm{Zn}, 5,000 \mathrm{mg} \mathrm{kg}{ }^{-1}$; $\mathrm{Cu}, 1,500 \mathrm{mg} \mathrm{kg}^{-1}$; I, $200 \mathrm{mg} \mathrm{kg}^{-1}$; Co, $20 \mathrm{mg} \mathrm{kg}^{-1}$; and $\mathrm{Se}, 14 \mathrm{mg} \mathrm{kg}^{-1}$ ) was offered with free access in containers located in the pre-milking waiting yard. Fresh water was also offered ad libitum in the paddocks and in the premilking waiting yard.

A decrease in pre-grazing herbage mass along the trial was observed (average $3.069 \mathrm{~kg} \mathrm{DM} \mathrm{ha}{ }^{-1}$ for May vs. $2.051 \mathrm{~kg} \mathrm{DM} \mathrm{ha}^{-1}$ for June, respectively).

Cows were milked between $07.00 \mathrm{~h}$ and $08.00 \mathrm{~h}$ and $15.30 \mathrm{~h}$ and $16.30 \mathrm{~h}$ and milk yield was electronically measured at each milking time during the trial.

Blood coccygeal samples were obtained on weeks 4 , $5,6,8$, and 9 of the experimental period, following the afternoon milking of all cows $(17.00 \mathrm{~h})$. Blood was deposited into labeled tubes of $5 \mathrm{~mL}$ containing sodium heparin anticoagulant. Plasma was separated after centrifugation at $800 \mathrm{~g}$ for $10 \mathrm{~min}$, aliquoted in microtubes of $1.5 \mathrm{~mL}$ and frozen at $-20^{\circ} \mathrm{C}$ until analyses. After the experimental phase, the plasma samples were thawed and concentrations of BHBA were determined by the NAD-dependent enzymatic UV method (Ranbut ${ }^{\mathbb{}}$, Randox Laboratories, UK), NEFA using the enzymatic colorimetric method (NEFA [nonesterified fatty acids] assay, Randox Laboratories, UK), and urea by GLDH UV by the kinetic method (UREA liquiUV ${ }^{\circledR}$, Human Gesellschaft für Biochemica und Diagnostica mbH, Germany) using an auto-analyzer (Metrolab 2300, Wiener Lab., Argentina).

The experimental design was completely randomized with a $2 \times 2$ factorial arrangement of treatments to study milk yield and blood metabolites. The normality of the data was established using the Shapiro-Wilk test and homoscedasticity through the Levene test.

Treatments were compared using the Linear Mixed Effect Model procedure with the statistical software IBM $^{\circledR}$ SPSS $^{\circledR}$ Statistics (version 19, IBM SPSS Inc., Chicago, USA). The pairwise comparison between treatments was performed using Bonferroni test with a significance level of $95 \%(\alpha<0.05)$. The statistical model used was:

$$
\mathrm{Y}_{\mathrm{ijkl}}=\mu+\alpha_{\mathrm{i}}+\beta_{\mathrm{j}}+\mathrm{c}_{\mathrm{ijk}}+\tau_{1}+(\alpha \beta)_{\mathrm{ij}}+(\alpha \tau)_{\mathrm{il}}+(\beta \tau)_{\mathrm{j} 1}+\mathrm{e}_{\mathrm{ijk} \mathrm{l}} \text {, }
$$
in which $Y_{i j \mathrm{k}}$ is the response at time 1 on animal $\mathrm{k}$ of treatment group $\mathrm{j}$ in treatment group $\mathrm{i} ; \mu$ is the overall mean; $\alpha_{\mathrm{i}}$ is a fixed effect of treatment $\mathrm{i}$ (pasture allowance); $\beta_{\mathrm{j}}$ is a fixed effect of treatment $j$ (corn silage supplementation); $c_{i j k}$ is a random effect of animal $k$ of treatment group $j$ in treatment group $i$; $\tau_{1}$ is a fixed effect of time $1 ;(\alpha \beta)_{\mathrm{ij}}$ is a fixed interaction effect of treatment $i$ with treatment $j ;(\alpha \tau)_{i 1}$ is a fixed interaction effect of treatment $i$ with time $1 ;(\beta \tau)_{j 1}$ is a fixed interaction effect of treatment $\mathrm{j}$ with time 1 ; and $\mathrm{e}_{\mathrm{ijk}}$ is the random error at time 1 on animal $\mathrm{k}$ of treatment group $\mathrm{j}$ in treatment group $\mathrm{i}$.

\section{Results}

The increase in daily pasture allowance caused a decrease in plasma concentrations of BHBA by $0.21 \mathrm{mmol} / \mathrm{L}(\mathrm{P}<0.001)$, but did not modify plasma concentrations of NEFA or urea. On the other hand, increasing the corn silage supplementation increased mildly the plasma concentrations of BHBA $(\mathrm{P}=0.014)$ and NEFA $(\mathrm{P}=0.031)$ during the experiment by $0.11 \mathrm{mmol} / \mathrm{L}$ and $15.83 \mu \mathrm{mol} / \mathrm{L}$, respectively, and decreased the plasma concentrations of urea $(\mathrm{P}<0.001)$ by $0.56 \mathrm{mmol} / \mathrm{L}$. An interaction on plasma urea concentration was observed in the cows receiving moderate pasture allowance and high corn silage supplementation showing lower plasma urea concentrations $(\mathrm{P}<0.001)$, averaging $3.64 \mathrm{mmol} / \mathrm{L}$ (Table 2$)$.

During the experiment, plasma concentrations of BHBA were above $0.6 \mathrm{mmol} / \mathrm{L}$ in all treatments and increased above $1 \mathrm{mmol} / \mathrm{L}$ in the last two samplings (Figure 1a and 1d). $\beta$-hydroxybutyrate concentrations of moderate PA and high CS remained above the other treatments and were significant in samplings two-five and four, respectively. A difference was observed in the first sampling for NEFA (Figure $1 \mathrm{~b}$ and 1e) and an increase in NEFA concentrations was found for high pasture allowance in the second sampling but remained stable in the other samples (Figure 1b). The pasture allowance did not affect the urea concentrations (Figure 1c), but high corn silage supplementation significantly decreased the

Table 2 - Means of blood metabolites and milk production of each treatment

$\begin{array}{cccc}\text { BHBA } & \text { NEFA } & \text { Urea } & \text { Milk } \\ (\mathrm{mmol} / \mathrm{L}) & (\mu \mathrm{mol} / \mathrm{L}) & \begin{array}{c}\text { production } \\ (\mathrm{mmol} / \mathrm{L})\end{array} & \begin{array}{c}\left(\mathrm{kg} \mathrm{d}^{-1}\right) \\ \end{array}\end{array}$

\begin{tabular}{lcccc}
\hline & \multicolumn{4}{c}{ Pasture allowance (PA) } \\
$17 \mathrm{~kg} \mathrm{DM} /$ cow/d & $1.12 \mathrm{a}$ & 78.80 & 4.33 & $21.99 \mathrm{a}$ \\
$25 \mathrm{~kg} \mathrm{DM} / \mathrm{cow} / \mathrm{d}$ & $0.91 \mathrm{~b}$ & 90.90 & 4.39 & $23.18 \mathrm{~b}$ \\
$\mathrm{SEM}$ & 0.047 & 7.252 & 0.152 & 0.15 \\
$\mathrm{P}-$ value & $<0.001$ & 0.098 & 0.690 & $<0.001$ \\
& \multicolumn{4}{c}{ Corn silage supplementation (CSS) } \\
$4.5 \mathrm{~kg} \mathrm{DM} /$ cow/d & $0.96 \mathrm{a}$ & $76.94 \mathrm{a}$ & $4.64 \mathrm{a}$ & 22.53 \\
$9.0 \mathrm{~kg} \mathrm{DM} /$ cow/d & $1.07 \mathrm{~b}$ & $92.77 \mathrm{~b}$ & $4.08 \mathrm{~b}$ & 22.64 \\
$\mathrm{SEM}$ & 0.047 & 7.253 & 0.152 & 0.15 \\
$\mathrm{P}-\mathrm{value}$ & 0.014 & 0.031 & $<0.001$ & 0.600 \\
$\mathrm{PA} \times \mathrm{CSS}$ & 0.063 & 0.394 & $<0.001$ & 0.925 \\
\hline
\end{tabular}

BHBA - $\beta$-hydroxybutyrate; NEFA - non-esterified fatty acids; DM - dry matter; SEM - standard error of the mean.

a,b - values with different letters within a column denote significant differences between treatments $(\mathrm{P}<0.05)$ 
concentrations throughout the experiment (Figure 1f). A decrease between samplings was observed for week three in both treatments.

The increase in the daily pasture allowance resulted in an increase of $1.19 \mathrm{~kg} \mathrm{~d}^{-1}$ in milk production $(\mathrm{P}<0.001)$, whereas the corn silage supplementation had no effect (Table 2).

\section{Discussion}

The intensification of dairy production systems associated with the high genetic selection of animals increased milk production per cow, which imposes greater nutritive needs, predisposing the animals to the so-called production diseases (Nir, 2003; Mulligan and Doherty, 2008). These diseases occur due to imbalances between income, biotransformation, and output of metabolites, generating pathophysiological changes (Allen and Piantoni, 2013; Esposito et al., 2014). Unfortunately, most of these diseases are difficult to detect and can limit persistently the production of animals, generating a decline in the profitability of dairy farms (Kossaibati and Esslemont, 1997; Contreras, 1998; Risco and Benzaquen, 2011).
In recent years, the use of blood metabolites has acquired relevance for the study and diagnosis of nutritional imbalances due to its simplicity (Wittwer, 2000; Macrae et al., 2006). In this study, plasma concentrations of BHBA in all treatments were found above the range of normal values for dairy cows (averaging $1.01 \mathrm{mmol} / \mathrm{L}$ ), which are considered acceptable from 0.1 to $0.6 \mathrm{mmol} / \mathrm{L}$ in early lactation (Wittwer, 2012; Raboisson et al., 2014). Otherwise, values $\geq 0.6 \mathrm{mmol} / \mathrm{L}$ of BHBA are considered indicators of negative energy balance, and greater than $1.2 \mathrm{and} /$ or $1.4 \mathrm{mmol} / \mathrm{L}$ are indicative of subclinical ketosis (Geishauser et al., 1998; Duffield et al., 2009; Cucunubo et al., 2013). The increase in the daily pasture allowance had a positive effect by decreasing the BHBA concentrations, keeping the values below $1 \mathrm{mmol} / \mathrm{L}$. A similar response was reported by Ruiz-Albarrán et al. (2012), who offered the same pasture allowances in fall-calving dairy cows, averaging 1.33 vs. $1.14 \mathrm{mmol} / \mathrm{L}$, for moderate and high pasture allowances, respectively. The foregoing can likely be attributed to a greater herbage dry matter intake and the opportunity to be more selective consuming higher quality herbage in the cows grazing under a higher PA (Bargo et al., 2003; Morales et al., 2014). (a)
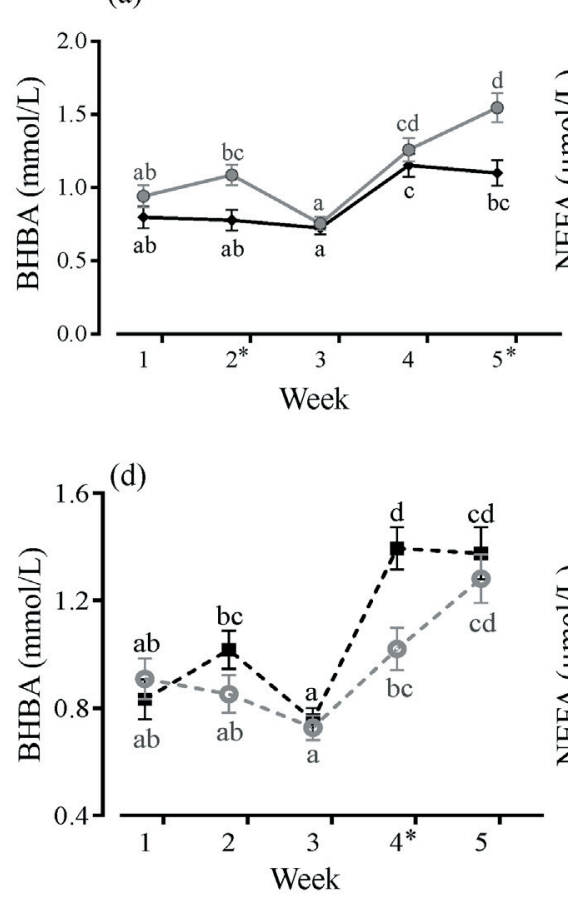

(b)

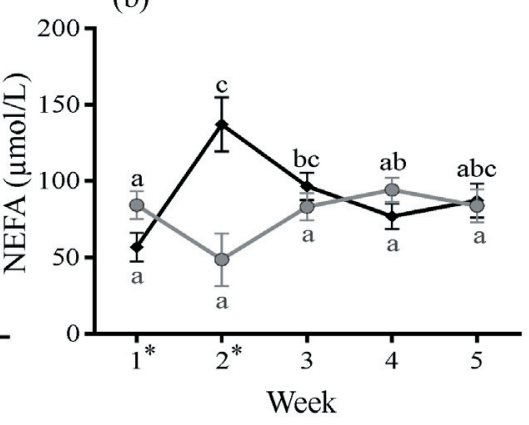

(e)

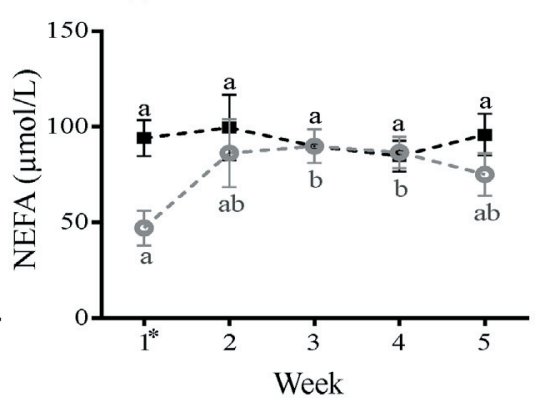

(c)

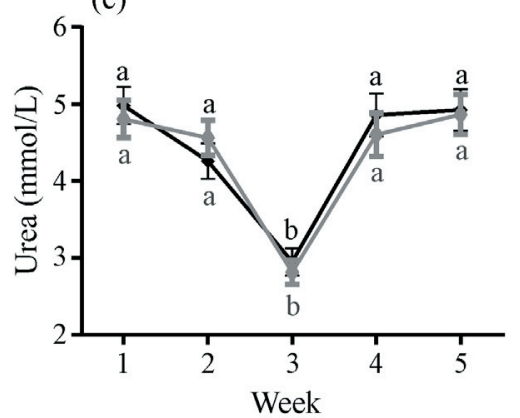

(f)

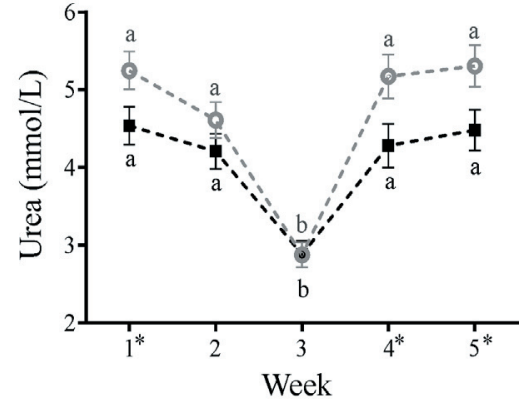

BHBA - $\beta$-hydroxybutyrate; NEFA - non-esterified fatty acids; SEM - standard error of the mean.

Blood samples were obtained at the experimental weeks $4,5,6,8$, and 9 , respectively.

Different letters denote statistical difference between samplings $(\mathrm{P}<0.05)$.

* Indicates statistical difference among samplings $(\mathrm{P}<0.05)$.

Figure 1 - Weekly variation of the plasma concentrations of BHBA (a,d), NEFA (b,e), and urea (c,f) ( $\bar{X} \pm$ SEM) of fall-calving dairy cows grazing under two pasture allowances $(\bullet 17 \mathrm{~kg} \mathrm{DM} / \mathrm{cow} / \mathrm{d}$ and $\bullet 25 \mathrm{~kg} \mathrm{DM} / \mathrm{cow} / \mathrm{d})$ and supplemented with corn silage $(\circ 4.5 \mathrm{~kg}$ $\mathrm{DM} /$ cow $/ \mathrm{d}$ and $\mathbf{a} 9.0 \mathrm{~kg} \mathrm{DM} /$ cow $/ \mathrm{d})$. 
The increase in plasma concentrations of BHBA during the last weeks of the trial was associated with the decrease in herbage mass recorded during that period $(\leq 2,000 \mathrm{~kg}$ DM ha ${ }^{-1}$ ), probably resulting in a decrease of herbage DM intake and therefore energy intake (Ruiz-Albarrán et al., 2012), highlighting the positive effect of high PA. However, as reported by Morales et al. (2014), the animal productivity, stage of lactation (around 100 days in milk), and the sampling time would not be consistent with cases of subclinical ketosis. Therefore, the high concentrations could be attributed to the time of sampling $(17.00 \mathrm{~h})$, when an increase in this metabolite was described in grazing cows (Noro et al., 2012), and to the butyrate content in the corn silage used, and butyric acid produced by the ruminal fermentation after eating, with subsequent metabolization to BHBA and absorption in the rumen wall (Noro et al., 2011). The differences between samplings are explained by the change in herbage mass during the experiment, altering the proportion of pasture and corn silage of the diet, and the physiological diurnal variation of BHBA (Nielsen et al., 2003).

The lack of response to the increase in corn silage supplementation could be attributed to a high substitution of pasture intake (0.9) (Morales et al., 2014), frequently observed in cows grazing low-mass pasture receiving preserved forages (Kellaway and Harrington, 2004; PerezPrieto et al., 2011). In addition, a null increase in total energy intake could be expected in both treatments, similar to those reported by Mitani et al. (2005). By contrast, Marcolino et al. (2014) reported an increase in milk production when offering 0,4 , and $8 \mathrm{~kg} \mathrm{DM}$ of corn silage associated with an increase in DM intake, suggesting a maximum of $4 \mathrm{~kg}$ DM of supplementation.

The plasma concentrations of NEFA were found within the physiological values in all treatments (averaging $84.8 \mu \mathrm{mol} / \mathrm{L}$ ), considering acceptable values $<600 \mu \mathrm{mol} / \mathrm{L}$ after calving (Adewuyi et al., 2005; Wittwer, 2012). The lower and stable concentrations are explained by a positive effect of corn silage supplementation on both treatments combined with the days in milk of the cows (only the first sampling was different) (van Knegsel et al., 2007). Moreover, the small increase was associated with high corn silage supplementation. Thomson et al. (2003) reported that NEFA is commonly used to determine nutritional disorders and health status of lactating dairy cows, but they suggested that blood plasma NEFA and triglyceride concentrations may also indicate energy status within physiological range, and that diurnal variations of blood metabolites are almost entirely due to level, frequency, and type of feeding.

The increment during the second sampling in Figure $1 \mathrm{~b}$ was attributed to a high-producing dairy cow $(27.7 \mathrm{~kg}$ of milk yield at the start of the experiment), which would have mobilized body reserves to offset the milk production increasing the concentration of the treatment. The observed NEFA values are in agreement with Mitani et al. (2005), who supplemented time-restricted grazing dairy cows with 2 or $4 \mathrm{~kg}$ DM of corn silage and did not find differences between treatments, recording NEFA values $<200 \mu \mathrm{mol} / \mathrm{L}$.

The plasma concentrations of urea were found within the reference interval in all treatments (averaging 4.36 $\mathrm{mmol} / \mathrm{L}$ ), considering acceptable values between 2.6 and $7.0 \mathrm{mmol} / \mathrm{L}$ (Wittwer, 2000). It corresponds to an end product of protein metabolism, used as a sensitive indicator of crude protein intake and ruminal protein-energy synchrony (Wittwer et al., 1993; Hwang et al., 2001; Melendez et al., 2003). The lower urea concentrations recorded in the high CS treatment are attributed to a better synchrony and utilization of energy and nitrogen release in the rumen, due to the energy intake through the corn silage (Barrientos et al., 2013). Moreover, the supplementation with corn silage allowed a better balance of the protein content of herbage, by diluting the protein concentration in the diet. The opposite effect was reported by Ruiz-Albarrán et al. (2012), who offered the same pasture allowance but supplementing with grass silage. The lower urea values recorded in the interaction between PA and CS supplementation was explained by the carbohydrate fractions of corn silage, which have different rates of ruminal degradations that generate a continuous energy contribution improving the ruminal synchronism with the herbage protein (Kim et al., 1999), similar to grazing cows supplemented with starch concentrate (Barrientos et al., 2013). The lower concentrations of urea in sampling three could not be associated with an effect of treatments, and would be explained by an effect of less protein intake (pasture) (Noro et al., 2011) for animal handling or adverse weather conditions, meaning a lower intake of pasture.

The positive effect in milk production with the increase in pasture allowance can be explained by the higher herbage intake and quality of the selected pasture (Perez-Prieto et al., 2011; Barrientos et al., 2013), whereas the lack of effect of the high supplementation was attributed to a similar total DM intake and energy intake in both treatments (Holden et al., 1995; Mitani et al., 2005; Morales et al., 2014).

\section{Conclusions}

Lower urea concentrations are observed when cows graze under moderate pasture allowances and are supplemented with a high amount of corn silage. Both corn silage treatments (low, $4.5 \mathrm{~kg}$, and high, $9.0 \mathrm{~kg} \mathrm{DM}$ ) are sufficient to maintain acceptable concentrations in 
the metabolites evaluated. Therefore, under restricted grazing conditions, low corn silage supplementation is recommended when cows are receiving a high pasture allowance, to promote a high pasture intake.

\section{Acknowledgments}

This study was funded by FONDECYT (project 1100513).

\section{References}

Adewuyi, A. A.; Gruys, E. and van Eerdenburg, F. J. C. M. 2005. Non esterified fatty acids (NEFA) in dairy cattle. A review. Veterinary Quarterly 27:117-126.

Allen, M. and Piantoni, P. 2013. Metabolic control of feed intake. Implications for metabolic disease of fresh cows. Veterinary Clinics: Food Animal Practice 29:279-297.

Bargo, F.; Muller, L. D.; Kolver, E. S. and Delahoy, J. E. 2003. Invited review: Production and digestion of supplemented dairy cows on pasture. Journal of Dairy Science 86:1-42.

Barrientos, L.; Noro, M.; Wittwer, F. and Pulido, R. 2013. Respuesta metabólica en vacas a pastoreo en otoño alimentadas con dos ofertas de pastura y suplementadas con concentrado amiláceo o fibroso. Revista Científica de la Facultad de Ciencias Veterinarias de la Universidad del Zulia 23:318-324.

Bjerre-Harpøth, V.; Friggens, N. C.; Thorup, V. M.; Larsen, T.; Damgaard, B. M.; Ingvartsen, K. L. and Moyes, K. M. 2012. Metabolic and production profiles of dairy cows in response to decreased nutrient density to increase physiological imbalances at different stage of lactation. Journal of Dairy Science 95:2362-2380.

Canseco, C.; Abarzúa, A.; Parga, J.; Teuber, N.; Balocchi, O.; Lopetegui, J.; Anwandter, V. and Demanet, R. 2009. Calidad nutritiva de las praderas. p.51-67. In: Manejo del pastoreo. Teuber, N.; Balocchi, O. and Parga, J., eds. Imprenta América, Osorno.

Contreras, P. 1998. Síndrome de movilización grasa en vacas lecheras al inicio de la lactancia y sus efectos en salud y producción de los rebaños. Archivos de Medicina Veterinaria 30:17-25.

Cucunubo, L.; Strieder-Barboza, C.; Wittwer, F. and Noro, M. 2013. Diagnóstico de cetosis subclínica y balance energético en vacas lecheras mediante el uso de muestras de sangre, orina y leche. Revista Científica de la Facultad de Ciencias Veterinarias de la Universidad del Zulia 23:111-119.

Dillon, P. 2006. Achieving high dry-matter intake from pasture with grazing dairy cows. p.1-26. In: Fresh herbage for dairy cattle the key to a sustainable food chain. Elgersma, A.; Dijkstra, J. and Tamminga, S., eds. Springer, Dordrecht.

Duffield, T. F.; Lissemore, K. D.; McBride, B. W. and Leslie, K. E. 2009. Impact of hyperketonemia in early lactation dairy cows on health and production. Journal of Dairy of Science 92:571-580.

Esposito, G.; Irons, P. C.; Webb, E. C. and Chapwanya, A. 2014. Interactions between negative energy balance, metabolic diseases, uterine health and immune response in transition dairy cows. Animal Reproduction Science 144:60-71.

Geishauser, T.; Leslie, K.; Kelton, D. and Duffield, T. 1998. Evaluation of five cowside tests for use with milk to detect subclinical ketosis in dairy cows. Journal of Dairy Science 81:438-443.

Gross, J.; van Dorland, H. A.; Bruckmaier, R. M. and Schwarz, F. J. 2011. Performance and metabolic profile of dairy cows during a lactational and deliberately induced negative energy balance with subsequent realimentation. Journal of Dairy Science 94:1820-1830.

Holden, L. A.; Muller, L. D.; Lykos, T. and Cassidy, T. W. 1995. Effect of corn silage supplementation on intake and milk production in cows grazing grass pasture. Journal of Dairy Science 78:154-160.

Hwang, S. Y.; Lee, M. J. and Peh, H. C. 2001. Diurnal variations in milk and blood urea nitrogen and whole blood ammonia nitrogen in dairy cows. Asian-Australasian Journal of Animal Sciences 14:1683-1689.

Ingvartsen, K. L.; Dewhurst, R. J. and Friggens, N. C. 2003. On the relationship between lactational performance and health: is it yield or metabolic imbalance that cause production diseases in dairy cattle? A position paper. Livestock Production Science 83:277-308.

Kellaway, R. and Harrington, T. 2004. Factors affecting response to supplementation. p.107-136. In: Feeding concentrates: supplements for dairy cows. Kellaway, R. and Harrington, T., eds. Landlink Press, Victoria.

Kida, K. 2003. Relationships of metabolic profiles to milk production and feeding in dairy cows. The Journal of Veterinary Medical Science 65:671-677.

Kim, K. H.; Choung, J. J. and Chamberlain, D. G. 1999. Effects of varying the degree of synchrony of energy and nitrogen release in the rumen on the synthesis of microbial protein in lactating dairy cows consuming a diet of grass silage and a cereal-based concentrate. Journal of the Science of Food and Agriculture 79:1441-1447.

Kossaibati, M. A. and Esslemont, R. J. 1997. The cost of production diseases in dairy herds in England. The Veterinary Journal 154:41-51.

Macrae, A. I.; Whitaker, D. A.; Burrough, E.; Dowell, A. and Kelly, J. M. 2006. Use of metabolic profiles for the assessment of dietary adequacy in UK dairy herds. Veterinary Record 159:655-661.

Marcolino, F. M.; Ribeiro-Filho, H. M.; Andrade, E. A.; Moraes, T. C. and Delagarde, R. 2014. Pasture intake and milk production of dairy cows grazing annual ryegrass with or without corn silage supplementation. Animal Production Science 54:1810-1816.

Melendez, P.; Donovan, A.; Hernandez, J.; Bartolome, J.; Risco, C.; Staples, C. and Thatcher, W. W. 2003. Milk, plasma, and blood urea nitrogen concentrations, dietary protein, and fertility in dairy cattle. Journal of the American Veterinary Medical Association 223:628-634.

Mitani, T.; Takahashi, M.; Ueda, K.; Nakatsuji, H.; Kondo, S. and Okubo, M. 2005. Effects of supplementary corn silage on the feed intake and milk production of time-restricted grazing dairy cows. Animal Science Journal 76:331-337.

Morales, A.; Grob, D.; Balocchi, O. and Pulido, R. 2014. Productive and metabolic response to two levels of corn silage supplementation in grazing dairy cows in early lactation during autumn. Chilean Journal of Agricultural Research 74:205-212.

Mulligan, F. and Doherty, M. 2008. Production diseases: A major health, welfare and economic problem on dairy farms. The Veterinary Journal 176:1-2.

Nielsen, N.; Ingvartsen, K. and Larsen, T. 2003. Diurnal variation and the effect of feed restriction on plasma and milk metabolites in TMR-fed dairy cows. Journal of Veterinary Medicine. A, Physiology, Pathology, Clinical Medicine 50:88-97.

Nir, O. 2003. What are production diseases, and how do we manage them? Acta Veterinaria Scandinavica 44:21-32.

Noro, M.; Borkert, J.; Hinostroza, G. A.; Pulido, R. and Wittwer, F. 2011. Variaciones diarias de metabolitos sanguíneos y su relación con el comportamiento alimenticio en vacas lecheras a pastoreo primaveral. Revista Científica de la Facultad de Ciencias Veterinarias de la Universidad del Zulia 21:25-130.

Noro, M.; Barboza, C.; Kuschel, D.; Pulido, R. and Wittwer, F. 2012. Variaciones diarias de parámetros ruminales y sanguíneos en vacas lecheras a pastoreo de primavera suplementadas con dos fuentes 
de nitrógeno no proteínico. Revista Científica de la Facultad de Ciencias Veterinarias de la Universidad del Zulia 22:154-162.

Payne, J. M.; Dew, S. M.; Manston, R. and Faulks, M. 1970. The use of a metabolic profile in dairy herds. Veterinary Record 87:150-158.

Pérez-Prieto, L. A.; Peyraud, J. L. and Delagarde, R. 2011. Substitution rate and milk yield response to corn silage supplementation of late-lactation dairy cows grazing low-mass pastures at 2 daily allowances in autumn. Journal of Dairy Science 94:3592-3604.

Poff, J.; Balocchi, O. and López, I. 2011. Sward and tiller growth dynamics of Lolium perenne L. as affected by defoliation frequency during autumn. Crop \& Pasture Science 62:346-354.

Pulido, R. G.; Muñoz, R.; Jara, C.; Balocchi, O. A.; Smulders, J. P.; Wittwer, F.; Orellana, P. and O'Donovan, M. 2010. The effect of pasture allowance and concentrate supplementation type on milk production performance and dry matter intake of autumn-calving dairy cows in early lactation. Livestock Science 132:119-125.

Raboisson, D.; Mounié, M. and Maigné, E. 2014. Diseases, reproductive performance, and changes in milk production associated with subclinical ketosis in dairy cows: A meta-analysis and review. Journal of Dairy Science 97:7547-7563.

Risco, C. A. and Benzaquen, M. 2011. Monitoring health and looking for sick cows. p.27-32. In: Dairy production medicine. Risco, C. A. and Melendez, P., eds. Blackwell Publishing Ltd., Oxford.

Ruiz-Albarrán, M.; Balocchi, O. A.; Noro, M.; Wittwer, F. and Pulido, R. G. 2012. Effect of increasing pasture allowance and grass silage on animal performance, grazing behavior and rumen fermentation parameters of dairy cows in early lactation during autumn. Livestock Science 150:407-413.
Ruiz-Albarrán, M.; Balocchi, O. A.; Noro, M.; Wittwer, F. and Pulido, R. G. 2016. Effect of the type of silage on milk yield, intake and rumen metabolism of dairy cows grazing swards with low herbage mass. Animal Science Journal 87:878-884.

Thomson, N.; Singh, K. and Kay, J. 2003. Diurnal variation in blood plasma metabolites and insulin of lactating dairy cows grazing pasture and supplemented with a high-lipid supplement either once or twice a day. Proceedings of the New Zealand Society of Animal Production 63:107-111.

Urdl, M.; Gruber, L.; Obritzhauser, W. and Schauer, A. 2015. Metabolic parameters and their relationship to energy balance in multiparous Simmental, Brown Swiss and Holstein cows in the periparturient period as influenced by energy supply pre- and post-calving. Journal of Animal Physiology and Animal Nutrition 99:174-189.

van Knegsel, A. T. M.; van den Brand, H.; Graat, E. A. M.; Dijkstra, J.; Jorritsma, R.; Decuypere, E.; Tamminga, S. and Kemp, B. 2007. Dietary energy source in dairy cows in early lactation: metabolites and metabolic hormones. Journal of Dairy Science 90:1477-1485.

Wittwer, F. G.; Opitz, H.; Reyes, J.; Contreras, P. C.; Böhmwald, H. 1993. Determinación de urea en muestras de leche de rebaños bovinos para el diagnóstico de desbalance nutricional. Archivos de Medicina Veterinaria 25:165-172.

Wittwer, F. 2000. Marcadores bioquímicos no controle de problemas metabólicos nutricionais em gado de leite. p.53-62. In: Perfil metabólico em ruminantes: seu uso em nutrição e doenças nutricionais. Gonzalez, F.; Barcellos, J.; Ospina, H. and Ribeiro, L., eds. Universidade Federal do Rio Grande do Sul, Porto Alegre.

Wittwer, F. 2012. Anexos. p.169-184. In: Manual de patología clínica veterinaria. 2nd ed. Wittwer, F., ed. Imprenta América, Valdivia. 